\title{
ТРУДОВАЯ МИГРАЦИЯ ИЗ КИТАЯ В УЗБЕКИСТАН
}

\author{
Чжуаньсунь Цяочу, аспирант, Белорусский государственный университет, Минск, Беларусь
}

DOI: https://doi.org/10.31435/rsglobal_conf/25062021/7604

Abstract. The article examines labor migration from China to Uzbekistan. The reasons, consequences and main problems of attracting labor from China are shown. The current state of economic and trade cooperation between China and Uzbekistan and the changes in the number of Chinese labor migrants in Uzbekistan in recent years are analyzed. And also, a recommendation was given to avoid negative consequences when attracting labor migrants from China.

Keywords: labor migration, labor force. labor resources, Uzbekistan, China.

Международная трудовая миграция является одной из важнейших проблем народонаселения и рассматривается не только как простое механическое передвижение людей, а как сложный социальный процесс, затрагивающий многие стороны жизнедеятельности общества. По справедливому замечанию Л. Галька, «не существует государства, которая на разных этапах своего развития той или иной мере не была задействована в мировых миграционных процессах» [1, c.125]. Более того, трудовая миграция становится все более актуальной проблемой в международных отношениях и становится одним из ключевых факторов трансформации и развития обществ во всех регионах. [2, с. 2].

В настоящее время, по оценке Министерства занятости и трудовых отношений Узбекистана, внешние трудовые мигранты составляют почти $22 \%$ всех трудовых ресурсов страны. С 1991 по 2019 г. экономика Узбекистана прошла через четыре этапа, каждый из которых характеризовался определенными демографическими, экономическими, политическими и другими факторами, оказывающими влияние на формирование внешней трудовой миграции на макроуровне. Эти этапы отражают: а) переход от плановой к рыночной экономике на фоне роста миграционного оттока на ПМЖ в 1990-2000 гг., б) ускорение экономического роста в 2000- 2009 гг. и формирование «мигрантских сетей» за рубежом, в) период замедления роста ВВП в отсутствие структурных реформ по стимулированию занятости и инвестиций в 2010-2015 гг., что способствовало активному росту трудовой миграции, г) этап новых социально-экономических реформ и усиление внимания руководства Узбекистана к миграционным процессам [3, с. 76].

Китайская трудовая миграция в Узбекистане включает торговую миграцию, бизнес миграцию и работу по найму. Сегодня наблюдается устойчивое присутствие китайской рабочей силы и бизнеса. Китайские менеджеры, инженерно-технические кадры, другие профессионалы и рабочие, заняты в приоритетных секторах сотрудничества КНР в Узбекистане. Они работают в основном на крупных китайских и совместных предприятиях, компаниях, подрядных организациях в энергетике, строительстве, сфере услуг.

Узбекистан, начиная с 2016 года, усилил внимание и изменил подход к миграции. К сожалению, в настоящий момент эта сфера все больше подвержена влиянию глобальных тенденций. Новая миграционная политика Узбекистана учитывает, как внутренние, так и внешние факторы. Сегодня республика, как и большинство других развивающихся государств, делает ставку на организованную трудовую миграцию.

Ранее в Узбекистане правовое регулирование ограничивалось организацией трудовой деятельности узбекских граждан за рубежом и иностранных - в Республике Узбекистан, работодатели должны были получить лицензию на использование ИРС.

В целях дальнейшего совершенствования системы внешней трудовой миграции, кардинального расширения ее организованных форм, обеспечения защиты трудовых и социальных прав граждан, выезжающих на работу за пределы республики, расширения вовлечения в предпринимательскую и трудовую деятельность вернувшихся из-за рубежа трудовых мигрантов, а также последовательной реализации задач, определенных Стратегией действий по пяти приоритетным направлениям развития Республики Узбекистан в 2017-2021 годах в Узбекистане принят ряд нормативно-правовых актов в области трудовой миграции. К их числу следует отнести: Трудовой кодекс [4]; Постановление Президента Республики Узбекистан от 5 июля 2019 года 
№ ПП-3839 «О дополнительных мерах по дальнейшему совершенствованию системы внешней трудовой миграции Республики Узбекистан» [5] и некоторые другие.

С 1 декабря 2018 г. требование о необходимости получения разрешений на привлечение иностранных кадров не применяется. Они могут работать до трех лет с правом неограниченного количества продлений, но не более трех лет в каждом случае; предлагаются и другие льготы и преференции. Трудовая иммиграция в Республике Узбекистан регулируется также международными соглашениями в рамках Содружества Независимых Государств (СНГ, 1991 г.).

В рамках Шанхайской организации сотрудничества (ШОС) Узбекистан вместе с Россией тесно взаимодействуют с Китаем в вопросах торгово-экономического сотрудничества, безопасности и предотвращения нелегальной миграции. Помимо инструментов ШОС, Китай в первую очередь сотрудничает с Республике Узбекистан в двустороннем формате, подписав договора для обеспечения безопасности и борьбы против «трех зол»: терроризма, сепаратизма и экстремизма на западных границах Китая [6, с. 203].

После смены политического лидера в 2016 г. Узбекистан уже два года активно наращивает сотрудничество с Китаем. Для не имеющего выхода к морю Узбекистана создание новой межрегиональной системы транспортных коммуникаций в рамках инициативы «Один пояс, один путь» принципиально важно, т.к. способствует созданию рабочих мест и росту занятости среди местного населения. В 2019 г. в Узбекистан въехало 19749 китайских граждан, из них на работу 4 257, с деловыми и служебными целями - 2739 и с коммерческими - 3590 человек [7].

По информации посла КНР в Республике Узбекистан, в стране на август 2020 г. было уже свыше 1000 предприятий с китайским капиталом. Судя по тому, как быстро растет в Узбекистане бизнес миграция и туризм из КНР, и, учитывая новую политику благоприятствования привлечению иностранных кадров, можно прогнозировать увеличение иммиграции в Узбекистане китайских профессионалов и предпринимателей.

В Узбекистане существуют опасения по поводу «чрезмерной» миграции из КНР и о том, что китайские работники создают «конкуренцию» местным на рынках труда. Однако рабочая сила из КНР занята, как правило, на китайских или совместных предприятиях, или работает вахтовым методом на отдаленных участках при строительстве газо- и нефтепроводов, либо занята в специфическом национальном бизнесе - китайских ресторанах и медицинских центрах, где нередко обслуживаются сами граждане из КНР. Доля китайской рабочей силы среди общего числа занятых Узбекистане невелика - 0,28 \%, и не оказывает существенного влияния на рынок труда [8, с. 13].

Незаконная иммиграция из Китая в Узбекистан незначительна, потому что китайское правительство требует от китайских предпринимателей строго соблюдать законы принимающей страны. В некоторых случаях имеют место незаконные пересечения границы, но наиболее распространенными из них являются нарушения внутреннего иммиграционного законодательства и трудового законодательства. В отдельных случаях китайские работники, не имеющие квалификации, предоставляют поддельные дипломы о высшем образовании, ложные приглашения, договора подряда, чтобы получить разрешение на работу.

Узбекистан имеет большой трудовой потенциал. Все зависит от того, как страна сможет им воспользоваться. Были времена, когда к мигрантам относились чуть ли не с призрением, но сегодня их проблемами всерьез занялись на самом высоком уровне. Уже принятые меры, безусловно, изменили ситуацию к лучшему, но их недостаточно. Важно понимать, что трудовые резервы - это залог процветания страны, возможность создания будущей сильной экономики. Дело не только и не столько в деньгах, которые люди зарабатывают на чужбине, отсылая на родину - дело в полученных знаниях и опыте.

Таким образом, в заключение можно сказать, что трудовая миграция из Китая становится неотъемлемым элементом на рынке труда Узбекистана. Китайский бизнес и рабочая сила вносят существенный вклад в развитие отдельных отраслей экономики Узбекистана. В тоже время трудовая миграция сопровождается рядом негативных явлений, связанных с неотработанностью организационных вопросов регулирования импорта рабочей силы. 


\section{ЛИТЕРАТУРА}

1. Галька, Л. Глобализация и трудовая миграция: необходимость политики, основанной на правах человека / Л. Галька, П. Таран // Век глобализации. - 2017. - № 1. - c. 66-88

2. Жуань Чжэнъюй, 跨国人口迁移与国家安全一项非传统安全因素的研究 [Транснациональные перемещения населения и национальная безопасность - исследование нетрадиционных факторов безопасности] / Жуань Чжэнъюй // 暨南大学. - 2003.- c. 2.

3. Бондаренко, К.А. Влияние трансформации социокультурных факторов на процессы внешней трудовой миграции Узбекистана / К. А. Бондаренко // Пространственная экономика. - 2020. - Т. 16. - № 3. - с. 76-108.

4. Трудовой кодекс Республики Узбекистан (Утвержден Законом Республики Узбекистан от 21 декабря 1995 года) // Ведомости Олий Мажлиса Республики Узбекистан, 1996 г., N 1

5. Постановление Президента Республики, Узбекистан от 5 июля 2019 года № ПП -3839 «О дополнительных мерах по дальнейшему совершенствованию системы внешней трудовой миграции Республики Узбекистан»//Собрание законодательства Республики Узбекистан, 9 июля 2018 г., N 27, с. 552

6. Садовская, Е.Ю. Инициатива Китая «Пояс и путь» и ее влияние на трудовую миграцию в Казахстане / Е.Ю. Садовская // Миграция как ресурс социально-экономического и демографического развития. Сборник статей. Сер. "Демография. Социология. Экономика" Под редакцией: Рязанцева С.В., Храмовой М.Н., Максимовой А.С. - М., 2019. - с. 201-207.

7. Доклад о миграции в мире 2020 - Международная организация по миграции. Retrieved from https://publications.iom.int/system/files/pdf/final-wmr_2020-ru.pdf. - Дата доступа: 25.02.2021.

8. Садовская, Е.Ю. Аналитический доклад Инициатива Китая “Пояс и Путь” и ее влияние на миграционные потоки и политику в Центральной Азии / Е.Ю. Садовская Retrieved from https://www.pragueprocess.eu/documents/repo/151/CA_China_Analytical_Report_Sadovskaya_RU.pdf. - Дата доступа: 25.02.2021. 